University Heart Journal

Vol. 4 No. 2 July 2008

\title{
Study on serum Lipoprotein (a) level in preeclamptic Bangladeshi women
}

\author{
Noor-E-Ferdous ${ }^{1}$, Mahmuda Khatun ${ }^{2}$, Md. Abu Siddique ${ }^{3}$, Asma U1 Hosna ${ }^{1}$, Shirin Akter Begum ${ }^{1}$ \\ and Md. Khurshed Ahmed. ${ }^{3}$ \\ ${ }^{1}$ Department of Obstetric \& Gynaecology, Bangabandhu Sheikh Mujib Medical University, Shahbag, Dhaka. \\ ${ }^{2}$ Department of Obstetric \& Gynaecology Sir Salimullah Medical College Hospital, Dhaka. \\ ${ }^{3}$ Department of Cardiology, Bangabandhu Sheikh Mujib Medical University, Shahbag, Dhaka. \\ Address for Correspondence \\ Dr. Noor-E-Ferdous, Assistant Professor, Department of Obstetric \& Gynaecology, BSMMU, Shahbag, Dhaka.
}

Email : nimmidoel@yahoo.com

\begin{abstract}
It is a case control study which was design to know the association of serum Lipoprotein (a) level in preeclamptic (PE) in women. This study was carried out in department of Obstetrics and Gynecology, Sir Salimullah Medical College Hospital, Mitford, Dhaka.

Total number of subjects was 100 . Out of which 50 were cases and 50 were controls. Cases were physically and clinically proved PE patients. Controls were age, parity and gestational age matched. Three ml of blood were collected from each subjects, serum fasting LP(a) level were measured The mean age of study group was $24.49 \pm 6.48$ years. Serum Lipoprotein(a) level was $51.51 \pm 29.38 \mathrm{mg} / \mathrm{dl} \mathrm{Vs} 17.40 \pm 7.89 \mathrm{mg} / \mathrm{dl}$ in cases and controls respectively. This difference was statistically significant $(\mathrm{p}<0.001)$. Mean serum Lipoprotein(a) level was found to be raised in severe preeclampsia $(74.87 \mathrm{mg} / \mathrm{dl})$ and lowest in control subject Severe preeclampsia was found to be associated with higher level of lipoprotein (a) than both control $(\mathrm{p}<0.01)$ and mild preeclamptic $(\mathrm{p}<0.01)$ subjects. Mild preeclampsia was also found to have higher average serum Lipoprotein $(\mathrm{a})$ than the normal $(\mathrm{P}<0.01)$ subjects.
\end{abstract}

Key Words

Lipoprotein(a), Preeclampsia, Bangladeshi women.

\section{Introduction}

Preeclampsia (PE) is a hypertensive disorder of pregnancy characterized by generalised inflammatory state and endothelial dysfunction resulting in disseminated microangiopathic disease with vasospasm and hypercoagulation. ${ }^{1}$ It is a serious complication of the second half of pregnancy. This disease is a leading cause of foetal growth retardation, infant morbidity, mortality, and maternal death. ${ }^{9}$ The world wide incidence of preeclampsia is still high inspite of the significant improvement of the mother and child care over the last decades. All over the world PE is the $3^{\text {rd }}$ leading cause for maternal mortality and the 7 th leading cause for the perinatal mortality. ${ }^{3}$ In Bangladesh the incidence of PE is very high. It is about $10 \%$ to $15 \%$ of all deliveries. ${ }^{8}$ In this country, only $2.3 \%$ women end their pregnancies under medical supervision. ${ }^{17}$ and the rest of them have no access to obstetric care. As a result most PE cases remain unrecognized until severe complications, such as eclampsia. Eclampsia accounts for about $16 \%$ of maternal mortality in our country and PE is the leading cause of premature termination, intrauterine growth retardation,perinatal mortality and morbidity. Eclampsia is a preventable disease if PE is detected early and treated an early stage.
This clinical condition was first discovered over 100 years ago, but still it pathology remains obscure. The pathogenesis of preeclampsia continues to be a challenge. Several lines of evidence suggests that preeclampsia is a multietiologic syndrome with heterogeneous biologic pathways. ${ }^{13}$ Among them genetic predisposition immunologic, circulatory, uterine vascular changes and endothelial dysfunction are important. The most accepted theory about etiology of PE is endothelial dysfunction. ${ }^{9}$ The causes of endothelial injury are multifactorial. ${ }^{15}$ In preeclampsia, characteristics pathological lesion in the uteroplacental bed is a necrotizing arteriopathy consisting of fibrinoid necrosis, accumulation of foam cells or lipid laden macrophages in the decidua, fibroblast proliferation and a perivascular infiltrate"acute atherosis" causing reduced placental perfusion. The similarity between leisons of preeclampsia and atherosclerosis has led to speculations of common pathophysiological pathway. Until now the most accepted etiopathogenesis of pre-eclampsia is endothelial injury and most recently by several authors Lipoprotein(a) has been linked to vascular endothelial cell injury in PE and its consequences ${ }^{18}$ Lipoprotein (a) $[\mathrm{Lp}(\mathrm{a})]$, a circulating lipoprotein particle,is formed by attachment of carrier protein, apolipoprotein (a) apo(a), to a low density lipoprotein (LDL) like particle. The 
gene coding for apo(a) has been localized to the long arm of chromosome 6 (q26-27), close to plasminogen gene. ${ }^{12}$ It has been found to be enhance blood coagulation by competeting with plasminogen for its binding site on fibrin clots and endothelial cells. This action is believed to be mediated by structural homology (>90\%) between apolipoprotein (a) and plasminogen. The activation of plasminogen to form plasmin is the essential step for the lysis of fibrin by plasminogen. ${ }^{4}$ Many studies have demonstrated the elevated Lp(a) levels are associated with atherogenesis and myocardial infraction. ${ }^{1}$ Both vitro and vivo data indicate that $\mathrm{Lp}(\mathrm{a})$ is involved in the thrombotic and atherosclerotic processes that lead to reduced blood flow. ${ }^{4}$ This action might be associated with the action of $L p(a)$ on fibrinolysis, the accumulation of $\mathrm{Lp}(\mathrm{a})$ within the lesions and the function of endothelial cells. ${ }^{17} \mathrm{Lp}(\mathrm{a})$, circulating lipoprotien, is accepted as an independent risk factor for premature coronary heart disease and atherosclerotic lesions has supplemented early in this $\operatorname{Lp}(\mathrm{a})$. There is increased risk of coronary heart disease if $\mathrm{Lp}(\mathrm{a})$ concentration is above $30 \mathrm{mg} / \mathrm{dl} .{ }^{17}$

Normal gestation is associated with a progressive rise in $\mathrm{Lp}$ (a) and this association might contribute to pre-eclampsia in some individuals. ${ }^{17} \mathrm{Lp}$ (a) were elevated in the women at risk in developing IUGR very early preterem delivery ( $<30$ weeks of gestation) and foetal or neonatal loss ${ }^{2}$. In as recent review, there is a additive risk for atherosclerotic disease in women with past history of preeclampsia was estimated to be increased seven fold. ${ }^{14}$ Women who previously had eclampsia/ preeclampsia have a two to six fold higher risk of dying from ischemic heart disease than women who only developed hypertension during pregnancy. ${ }^{6}$

Husby et. al. ${ }^{8}$ reported two sisters with very high levels of $\mathrm{Lp}(\mathrm{a})$, both with a history of severe preeclampsia.

\section{Materials and Methods}

This case control study. carried out in the Department of Obstetrics and Gynecology of Sir Salimullah Medical College Hospital, Mitford, Dhaka, Bangladesh. The study was conducted in 100 pregnant women. Among them 50 diagnosod preeclamptic women were enrolled as cases. Cases were divided in to two groups:

Mild PE was diagnosed by BP with $>140 / 90 \mathrm{~mm}$ of $\mathrm{Hg}$ or $<160 / 110 \mathrm{~mm}$ of $\mathrm{Hg}$ with proteinuria of 2 random clean catch urine specimen with $2+$ or more on reagent strip.

Severe PE was diagnosed by BP $>160 / 110$ mm of $\mathrm{Hg}$ with proteinuria of $3+$ or more in dipstick test.

Controls were normotensive pregnant women uncomplicated by pregnancy-induced hypertension and proteinurea care was taken to select, equal number of subjects in each group having similar age, and comparable gestational age and to represent the same social stratum. Any subject with diabetes mellitus, chronic renal failure, preexisting hyperlipidaemia, essential hypertension was excluded. Aims and objectives of study were to investigate the association of $\mathrm{Lp}(\mathrm{a})$ in pre eclampsia .

\section{Results}

Total one hundred subjects were studied, among them 50 were cases and 50 were controls. Cases were admitted in Obstetric and Gynaecoloty Department Sir Salimullah Medical College Hospital, Mitford, clinically diagnosed as preeclampsia either mild or severe PE. Controls were age, parity and gestational age matched. They were uncomplicated by pregnancy-induced hypertension and proteinurea. Care was taken to select, equal number of subjects in each group having similar age, and comparable gestational age and to represent the same social stratum.

The mean age of study group was $24.49 \pm 6.48$; maximum cases were in 3rd decade of life. (Table 1) Lipoprotein(a)l level was $51.51 \pm 29.38 \mathrm{mg} / \mathrm{dl} \mathrm{Vs} 17.40 \pm 7.89 \mathrm{mg} / \mathrm{dl}$ in cases and controls respectively. This difference was statistically significant $(\mathrm{p}<.001)$. With the higher level of preeclampsia mean Lipoprotein(a) level tends to be higher. Mean serum Lipoprotein(a) level was found to be highest in severe preeclamsia group $(74.87 \mathrm{mg} / \mathrm{dl})$ and lowest in control subject. One way ANOVA reveals highly significant statis tical difference of serum Lipoprotein (a) level between the difference level of preeclamsia (F 3.236 P <.01).

Table I Baseline characteristics of study patients

\begin{tabular}{|l|c|c|}
\hline \multirow{2}{*}{} & \multicolumn{2}{|c|}{ Group } \\
\cline { 2 - 3 } & Study group & Control group \\
\hline Primi & $31(62 \%)$ & $18(36 \%)$ \\
\hline Multi & $19(38 \%)$ & $32(64 \%)$ \\
\hline Age (years ) & $25.54+8.8$ & $23.44+4.17$ \\
\hline
\end{tabular}

All the data are expressesd as mean $+\mathrm{SD}$ and percent

Table I shows the distribution of the respondents by age and obstetric history. Among the preeclamtic women majority of the subject and among control subjects were primi gravid. Odds Ratio demonstrated around three times more risk of developing pre eclampsia among the primi gravid women then their multi gravid counter part.

Table II: Comparison of $\mathbf{2 4}$ hour total urinary protein between mild preeclampsia\& severe preeclampsia

\begin{tabular}{|c|c|c|c|}
\hline \multirow[b]{2}{*}{ Parameter } & \multicolumn{2}{|c|}{ Group } & \multirow[b]{2}{*}{ p value } \\
\hline & $\begin{array}{c}\text { Mild PE } \\
(\text { Mean + SD) }\end{array}$ & $\begin{array}{c}\text { Severe PE } \\
(\text { Mean + SD) }\end{array}$ & \\
\hline $\begin{array}{l}\text { Urinary } \\
\text { Protein } \\
\text { gm/24hr }\end{array}$ & $2.06+5.36$ & $4.39+1.55$ & $\mathrm{p}<0.046$ \\
\hline
\end{tabular}

$\mathrm{p}$ value $<0.05$ is significant 
Table II compares the level of 24 hour urinary protein between types of pre eclamsia. Average protein content was $2.33 \mathrm{gm} / 24$ hour urine higher among subject with severe preeclamsia then the women with mild preeclamsia.

Table- III. Distribution of Lipoprotein(a) (mg/dl ) in cases \& control.

\begin{tabular}{|c|c|c|c|}
\hline \multirow{2}{*}{ Parameter } & \multicolumn{2}{|c|}{ Group } & \multirow{2}{*}{ p value } \\
\cline { 2 - 3 } & $\begin{array}{c}\text { Study group } \\
\text { Mean + SD }\end{array}$ & $\begin{array}{c}\text { Control group } \\
\text { Mean + SD }\end{array}$ & \\
\hline $\begin{array}{c}\text { Lipoprotein } \\
\text { (a) }\end{array}$ & $51.51+29.38$ & $17.40+7.89$ & $\mathrm{p}<.001$ \\
\hline
\end{tabular}

$\mathrm{p}$ value $<0.05$ is significant

The table above showing mean lipoprotein(a) level in study groups. The mean value was $51.51 \pm 29.38 \mathrm{mg} / \mathrm{dl}$ and $17.40 \pm 7.89 \mathrm{mg} / \mathrm{dl}$ for cases and controls respectively there was a statistically significant difference of mean lipoprotein(a) level between cases and controls $(p<0.001)$.

Table IV: Distribution of Lipoprotein (a) (mg/dl) level according to level of preeclampsia

\begin{tabular}{|c|c|c|c|}
\hline $\begin{array}{c}\text { Level of } \\
\text { preeclampsia }\end{array}$ & $\mathbf{N}$ & $\begin{array}{c}* \text { Lp(a) level } \\
\text { (Mean } \pm \text { SD) }\end{array}$ & p value \\
\cline { 1 - 3 } Normal & 50 & $17.40 \pm 7.89$ & \multirow{2}{*}{$\begin{array}{c}\text { F } 3.236 \\
\text { P } 0.001\end{array}$} \\
\cline { 1 - 3 } Mevere & 21 & $74.87 \pm 32.74$ & \\
\hline
\end{tabular}

* Lipoprotein(a) level (mg/dl)

$\mathrm{P}<0.05$ was significant

Table IV shows mean serum Lipoprotein (a) level was found to be highest in severe preeclamsia group (74.87 $\mathrm{mg} / \mathrm{dl}$ ) and lowest in control subject.

Table V: Comparison of Lipoprotein(a) (mg/dl) level among different level of preeclampsia

\begin{tabular}{|ccc|c|c|c|}
\hline \multicolumn{2}{|c|}{ Type of preeclampsia } & $\begin{array}{l}\text { Mean } \\
\text { Difference }\end{array}$ & Std. Error & pvalue \\
\hline Normal & Vs & Mild & -17.18 & 3.79 & 0.001 \\
\hline Normal & Vs & Severe & -57.46 & 4.22 & 0.001 \\
\hline Mild & Vs & Severe & -40.28 & 4.65 & 0.001 \\
\hline
\end{tabular}

$\mathrm{P}<0.05$ was significant

In Table V Post hoc (Hochberg) multiple comparison was also performed to explore the nature of difference of Lipoprotein(a) (mg/dl) level among different level of preeclampsia. Severe preeclampsia was found to be associated with higher level of Lipoprotein(a) then both control $(\mathrm{P}<0.01)$ and mild preeclamptic $(\mathrm{P}<0.01)$ subjects. Mild preeclampsia was also found to have higher average serum Lipoprotein(a) than the normal $(\mathrm{P}<0.01)$ subjects.

\section{Discussion}

The precise aetiology of preeclampsia is still obscure. Ness \& Robert suggested preeclampsia as a multietiologic syndrome with heterogeneous biologic pathways. ${ }^{13}$ In search of causal mechanism, researcher's world wide had been pondering several pathways and attempting to indict various factors. Several postulations has already been made by various authors, until now the most accepted etiopathogenesis of preeclampsia is endothelial injury and most recently by several authors Lipoprotein (a) has been linked to vascular endothelial cell injury in PE and its consequences. ${ }^{18}$ Abnormal lipid metabolism has been proposed as a pathogenic factor of preeclampsia; however its role is still unclear. ${ }^{11}$

Present endeavour studied the relationship between maternal plasma Lipoprotein (a) concentrations and risk of preeclampsia. A total of 50 preeclamptic patients and 50 normotensive control subjects were included in this study, conducted at department of Obstetric and Gynaecology, Sir Salimullah Medical College Hospital, Mitford, Dhaka over January 2006 to December 2006.

Both cases and controls were recently admitted patients, diagnosed recently and having no complication or co-morbidity. Due emphasis were put on the selection of controls particularly the matching of background features which seems to have confounding potential on the hypothesis. A disparity of age up to two years was accepted between cases and controls.

Background features and demographic information were meticulously assessed to elucidate any bias and to control as well. Most subjects in both the group were of $3^{\text {rd }}$ decade In the present investigation lipid profile has not been assessed due to inadequate logistic support and time constrain. However, many authors pronounced dyslipidemia of having etiologic importance.

There are studies which have shown elevated Lp(a) levels in preeclampsia and the association of severity of disease and level of $\mathrm{Lp}$ (a). 2,4,21,22 Wang et al described small cohort study a statistically significant difference of Lp(a) concentrations in third trimester of women with preeclampsia compared to women with normal pregnancies. ${ }^{21}$ The study included only 18 mild and 8 severe preeclamptic patients, 24 normal pregnant women. They measured the highest levels in women with severe preeclampsia and intermediate levels in mild preeclamtic patients.

Bar et. al. ${ }^{4}$ conducted a cross sectional study which included 16 women with preeclampsia, 35 normotensive pregnant women and 18 healthy nonpregnant.Plasma concentrations of $\mathrm{Lp}(\mathrm{a})$ were significantly higher in women with preeclampsia thah normotensive pregnant women.

Van Pampus et.al. ${ }^{20}$ observed statistically significant higher concentration of $\mathrm{Lp}(\mathrm{a})$ in 40 women with a history of 
severe preeclampsia in comparasion with women who had a hisroy of preeclampsia with HELLP syndrome.

Aksoy et. al. ${ }^{2}$ described in case control study a statistically significant difference in $\mathrm{Lp}(\mathrm{a})$ in 13 severe preeclamtic and 15 mild PE and 15 healthy pregnant women.

This study also showed similar results in accordance with other previous reports Multivariate analysis, considering most confounders, Triglyceride \& HDL in particular, might have been considered for unbiased result after controlling necessary intervening variables. As Lipoprotein (a) itself is a derivative of body lipid, it should have been given due attention.

There has been wide range of disagreement regarding serum Lipoprotein(a) level nd development of preeclampsia among pregnant women. Varied study setting and diverse sample structure might have contributed to such dissimilarity in study findings. Consensus regarding the role of Lipoprotein(a) in preeclampsia and its consequence is important. Hence, large-scale, multi-centred study with larger logistic support is hereby recommended.

\section{Conclusion}

In the present study serum Lipoprotein (a) level was found to be significantly higher in preeclamptic patient then controls. It signifies strong association of $\mathrm{Lp}(\mathrm{a})$ with preeclampsia in our Bangladeshi women. Higher the severity of preeclampsia serum lipoprotein(a) tends to be higher. Severe preeclampsia was found to be associated with higher level of lipoprotein (a) than both control and mild preeclamptic subjects. We included a small number of subjects - only 50 cases and 50 controls. It is difficult to draw conclusion. We recommend further large-scale studies to establish the association of lipoprotein (a) with preeclampsia in our country.

\section{References}

1. Averna MR. Barbagallo CM, Ocello S, Doria O, Davi G, Safidi V, Alberio R, Natabartolo A. Lp(a) levels in patients undergoing aorto-coronary bypass surgery. Eur Heart J. 1992 ;13(10): 1405-09.

2. Aksoy H, KumtepeY, AkcayF, Yildrim, AK.Correlation of Pselectin and lipoprotein (a) and lipid parameters in preeclampsia.Clin Exp Med 2002;2: 39-43

3. Berg K. High levels of $\mathrm{Lp}(\mathrm{a})$ lipoprotein in a family with cases of severe pre-eclampsia. Clin Genet; 1996: 50:47-49.

4. Bar J,Harell D,Bardin R. The elevated level of lipoprotein (a) concentration in preeclampsia precede the development of the disorder.Thromb. Research $2002 ; 105:$ 19-23

5. Chien PFW, Khan KS, Arnoff N. Magnesium sulphate in the treatment of eclampsia and preeclampsia: an overview of the evidence from randomized trials. Br J Obset Gynaecol 1996; 103: 1085-91.

6. Dahlen GH, Guyton JR,Attar M,Farmar.JA, Kautz JA,Gotto AM.. Association of levels of lipoprotein Lp(a), plasma lipids, and other lipoprotein with coronary artery disease documented by angiography. Circulation 1986;74(4):75865 .

7. Davis GL Hemostatic changes associated with normal and abnormal pregnancies. Clin Lab Sci 2000; 13: 223-28.

8. Husby H, Roald B, Schjetlein R, Nesheim B-I, Berg K. High levels of $\mathrm{Lp}(\mathrm{a})$ lipoprotein in a family with cases of severe pre-eclampsia. Clin Genet 1996; 50:47-49.

9. Iris Shai, Rimm EB, Hankinson SE, Manson JE,Rifai.N, Stampfer MJ, Lipoprotein(a) and coronary heart disease among women: beyond a cholesterol carrier. European Heart Journal 2005; 1633-39.

10. Jonsdottir LS, Arngrimsson R, Geirsson RT, Sigvaldason H, Sigfusson N. Death rates from ischemic heart disease in women with a history of hypertension in pregnancy. Acta Obstel Gynecol Scand 1995 ; 74:772.

11. Khatoon MS. Clinical profile and management of eclampsia in SSMCH and MF, Dhaka. Bangladesh college of Physician and Surgeons (Dessertation) 1992

12. Khaliq . F, Singhal U, Arshad Z, Hossain MM.. Study of serum lipid \&lipoprotein(a) in preecclampsia with special reference to parity. Indian.J. physiol pharmacol 2002;44:192

13. Lenfant C, Gifford RW, Zuspan FP, Consensus report : national high blood pressure education program working group report on high blood pressure in pregnancy. Am J Obstet Gynecol 1990;163:1689-712.

14. Llurba E,Casals E, Dominguez C,Julian D, Mercade I, Crispi $\mathrm{F}$ et al. Atherogenic lipoprotein subtraction profile in preeclamptic women with and without high triglycerides: Different pathophysiologic subsets in preeclampsia. Metabolism 2005;54:1504-09.

15. Lindahl G, Gersdrof W, Menzel HJ,Duba C, Hammersmith S,Utermann G. The gene for Lp(a)-specific glycoprotein is closely linked to the gene for plasminogen on chromosome 6. Hum Genet 1989; 81: 149-52.

16. Ness RB and Roberts JM, Heterogenous causes consituting the syndrome of preeclampsia:a hypothesisd its implication. Am .J Obstet gynecol 1996; 175:1365-70.

17. Rodie VA, Freeman DJ, Satter N, Greer I A. Preeclampsia and cardiovascular disease: metabolic syndrome of pegnancy? Atherosclorosis 2004; 175:189-202.

18. Roberts JM and Redman CWG. Preeclampsia More than pregnancy induced hypertension. Lancet1993;341:1447-54

19. Sattar N, Clark P, Greer IA, Shepherd J, Packard CJ.Lipoprotien (a) level in normal pregnancy \& in pregnancy complicated with preeclampsia.Atherosclerosis 2000;148:407-

20. Van Pampus MG, Koopman MMW, Wolf H, Harry R Martin $\mathrm{H}$, Abraham ELipoprotein(a) concentrations in women with a history of severe preeclampsia; a case control study. Thromb Haemost 1999; 82:10-13.

21. Wang J, Mimuro S, Lahoud R, Trudinger B, Li Wang X. Elevated level of lipoprotein(a) in women with preeclampsia. Am J Obstet Gynaecol 1998; 178:146-49.

22. Yasmin HA, Rahman MH, Chowdhury FK. Baseline survey for assesment of emergency obstetric care service in Bangladesh Institute of Research for Promotion of Essential and Reproductive Health and Technoiogies 1995 (BIRPERHT). 